\title{
HONO measurement by differential photolysis
}

\author{
Chris Reed $^{1}$, Charlotte A. Brumby ${ }^{3}$, Leigh R. Crilley ${ }^{5}$, Louisa J. Kramer ${ }^{5}$, William J. Bloss ${ }^{5}$, Paul W. Seakins ${ }^{3,4}$, \\ James D. Lee ${ }^{1,2}$, and Lucy J. Carpenter ${ }^{1}$ \\ ${ }^{1}$ Wolfson Atmospheric Chemistry Laboratories, Department of Chemistry, University of York, \\ Heslington, York, YO10 5DD, UK \\ ${ }^{2}$ National Centre for Atmospheric Science (NCAS), University of York, Heslington, York, YO10 5DD, UK \\ ${ }^{3}$ School of Chemistry, University of Leeds, Leeds, LS2 9JT, UK \\ ${ }^{4}$ National Centre for Atmospheric Science (NCAS), University of Leeds, Leeds, LS2 9JT, UK \\ ${ }^{5}$ School of Geography, Earth and Environmental Sciences, University of Birmingham, \\ Birmingham, B15 2TT, UK
}

Correspondence to: Chris Reed (chris.paul.reed@gmail.com)

Received: 18 January 2016 - Published in Atmos. Meas. Tech. Discuss.: 25 January 2016

Revised: 29 April 2016 - Accepted: 23 May 2016 - Published: 7 June 2016

\begin{abstract}
Nitrous acid (HONO) has been quantitatively measured in situ by differential photolysis at 385 and $395 \mathrm{~nm}$, and subsequent detection as nitric oxide (NO) by the chemiluminescence reaction with ozone $\left(\mathrm{O}_{3}\right)$. The technique has been evaluated by Fourier transform infrared (FT-IR) spectroscopy to provide a direct HONO measurement in a simulation chamber and compared side by side with a long absorption path optical photometer (LOPAP) in the field. The $\mathrm{NO}-\mathrm{O}_{3}$ chemiluminescence technique is robust, well characterized, and capable of sampling at low pressure, whilst solid-state converter technology allows for unattended in situ HONO measurements in combination with fast time resolution and response.
\end{abstract}

\section{Introduction}

Nitrous acid (HONO) is a major source of hydroxyl $(\mathrm{OH})$ radicals in the boundary layer (Elshorbany et al., 2008; Kim et al., 2014; Levy II, 1973). HONO can be formed homogeneously through reaction of nitric oxide (NO) with $\mathrm{OH}$, heterogeneously through several pathways, or emitted directly (Kleffmann, 2007; Lammel and Cape, 1996; Spataro and Ianniello, 2014; Su et al., 2011). HONO is formed heterogeneously on surfaces through the reaction of $\mathrm{NO}_{2}$ with $\mathrm{H}_{2} \mathrm{O}$ (Bröske et al., 2003). This heterogeneous formation of $\mathrm{HONO}$ is a net source of $\mathrm{OH}$ radicals in the troposphere and is an important mediator of air quality, particularly in pol- luted environments (Finlayson-Pitts et al., 2003; Gutzwiller et al., 2002; Lee et al., 2016). Combustion sources of HONO are direct emission from on-road vehicle exhausts (Rappengluck et al., 2013), aircraft and diesel emissions (Lee et al., 2011a), and biomass burning (Roberts et al., 2010). Emission from snowpack has also been documented (Beine et al., 2008; Zhou et al., 2001), and more recently biogenic sources of HONO have been identified from nitrite-producing bacteria (Oswald et al., 2013; Su et al., 2011) and soil crusts (Weber et al., 2015).

In urban areas HONO can be the major net source of $\mathrm{OH}$ (discounting radical cycling driven by e.g. NO), contributing up to $80 \%$ of daytime $\mathrm{OH}$ production in winter and $50 \%$ in summer (Elshorbany et al., 2008; Kleffmann, 2007; Villena et al., 2011b). However, the sources of HONO and the many processes by which it forms are not well understood (Kleffmann et al., 2006; Sörgel et al., 2011; Spataro and Ianniello, 2014; Villena et al., 2011a). There is a clear need for in situ measurement of HONO in order to better understand its chemistry and emissions.

Currently, methods of detecting HONO are either remotely through differential optical absorption spectroscopy (DOAS; Febo et al., 1996; Hendrick et al., 2014; Stutz et al., 2010) or by filter/denuder sampling (Acker et al., 2005, 2006; Febo et al., 1993, 1996; Ianniello et al., 2007). A variety of in situ techniques exist: namely, quantum cascadetuneable infrared laser differential absorption spectrometry (QC-TILDAS) (Lee et al., 2011b); ion drift chemical ioniza- 
tion mass spectrometry (ID-CIMS) (Levy et al., 2014); ambient ion monitor-ion chromatography (AIM-IC) (Markovic et al., 2012; Vandenboer et al., 2014); stripping coil-visible absorption photometry (SC-AP) (Ren et al., 2011); negativeion proton-transfer chemical ionization mass spectrometry (NI-PT-CIMS) (Roberts et al., 2010); incoherent broadband cavity-enhanced absorption spectroscopy (IBBCEAS) (Pusede et al., 2014); and, as used in this study, long path absorption photometry (LOPAP) (Heland et al., 2001). LOPAP has been characterized quite extensively by other authors (e.g. Clemitshaw, 2004; Kleffmann and Wiesen, 2008; K1effmann et al., 2006, 2013; Ródenas et al., 2013).

Here, we demonstrate the exploitation of a known HONO interference for photolytic $\mathrm{NO}_{2}$ conversion systems (Pollack et al., 2011; Ryerson et al., 2000; Sadanaga et al., 2010, 2014; Villena et al., 2012) to provide a simple photolytic technique for quantitative analysis of HONO.

\section{Experimental}

The differential photolytic HONO technique, henceforth referred to as pHONO, was developed from an existing fast $\mathrm{NO}_{x}$ analyser, described in Sect. 2.1. The photolytic converter is described specifically in Sect. 2.2. Characterization and calibration are described in Sects. 2.3 and 2.4. The precision, limit of detection, artefacts, interferences, and uncertainties are described in Sects. 2.5 and 2.6.

\subsection{Differential photolysis instrument}

Measurement were performed using a dual-channel Air Quality Design Inc. (Golden, Colorado, USA) instrument equipped with a UV-LED-based photolytic $\mathrm{NO}_{2}$ converter - commonly referred to as a blue-light converter (BLC) as described in Reed et al. (2016).

Briefly, a dual-channel NO chemiluminescence analyser operates in parallel with duplicated independent equipment. The two channels share a common inlet allowing for parallel calibration. One channel is equipped with a photolytic $\mathrm{NO}_{2}$ converter so that $\mathrm{NO}_{x}$ can be determined with that channel whilst also measuring NO concurrently. This allows for fast $\left(1 \mathrm{~Hz}\right.$ or greater) determination of $\mathrm{NO}$ and $\mathrm{NO}_{2}$. A chemiluminescent zero is taken every $5 \mathrm{~min}$ by increasing the $\mathrm{NO}+\mathrm{O}_{3}$ reaction time. Practically, the sample flow is diverted to a PFA volume so that $>99 \%$ of NO is converted; any residual chemiluminescence signal arises therefore from slower ( $\sim 2$ orders of magnitude) $\mathrm{O}_{3}+$ alkene reactions (Drummond et al., 1985).

In order to be able to also measure $\mathrm{HONO}$, the $\mathrm{NO}_{x}$ channel was redesigned so that the photolytic converter (Sect. 2.2) operates in a switching mode. That is, the two lamps of different wavelengths operate alternately on a $50 \%$ duty cycle. The lamps switch every $30 \mathrm{~s}$, allowing for $1 \mathrm{~min}$ time resolution data.

\section{$2.2 \quad \mathrm{NO}_{2}-\mathrm{HONO}$ photolytic converter}

Photolytic converters were based on those supplied by Air Quality Design and manufactured according to their proprietary standards (Buhr, 2004, 2007), and they are described in Reed et al. (2016). Two UV-LED arrays are positioned at opposing ends of a cavity which is highly reflective to UV. Sample gas is introduced at one end of the illuminated cavity, exiting at the other. NO in the sample exiting the converter is enhanced over the original by photolysis of $\mathrm{NO}_{2}$ or $\mathrm{HONO}$; thus by calibration of the conversion efficiency these can be quantified.

Modifications were made to the control of the UV-LED elements to allow independent switching of the lamps. The wavelength of one lamp was changed from standard $(395 \mathrm{~nm})$ to $385 \mathrm{~nm}$ in order to overlap better with the HONO absorption spectrum, whilst the actual UV-LEDs (3 W, LED Engin, Inc.) are more efficient and higher powered than those used in previous work (Reed et al., 2016).

The volume of the illuminated sample chamber is $16 \mathrm{~mL}$, which, with a standard flow rate of 1 standard $\mathrm{L} \mathrm{min}^{-1}$, gives a sample residence time of $0.96 \mathrm{~s}$, assuming plug flow, at standard atmospheric temperature and pressure (SATP). The $\mathrm{NO}_{2}$-to-NO conversion efficiency of the standard BLC with the sample flow of 1 standard $\mathrm{L} \mathrm{min}^{-1}$ was $\sim 89 \%$ with both lamps illuminated. Individual lamp conversion efficiencies were 72.9 and $81.3 \% \pm 0.1$ for the 385 and $395 \mathrm{~nm}$ lamps, respectively. Determination of the conversion efficiency is detailed in Sect. 2.4.

\subsection{Characterization}

Spectral radiograms of the UV-LED output were obtained using the same procedure and equipment described in Reed et al. (2016) using an Ocean Optics QE65000 spectral radiometer coupled to a $2 \pi$ quartz collector within a light-sealed chamber.

Figure 1 shows the measured spectral emission of two UVLED units of two different wavelengths; 385 and $395 \mathrm{~nm}$. Also shown is the absorption cross section of HONO, $\mathrm{BrONO}_{2}$, and the $\mathrm{NO}_{2}$ quantum yield (Burkholder et al., 2015). It is clear that there is greater overlap, calculated to be $30 \%$, of the HONO absorption features with the $385 \mathrm{~nm}$ LED than at $395 \mathrm{~nm}$. In Reaction (R2) we see that NO is produced stoichiometrically through the photolysis of HONO. In this way, illuminating an air sample at either wavelength yields a signal, which we shall denote as $\mathrm{NO}_{2}^{\dagger}$ and which represents the sum of contributions from $\mathrm{NO}_{2}$ and $\mathrm{HONO}$ (Reactions $\mathrm{R} 1+\mathrm{R} 2$ ) in differing proportions depending upon wavelength.

$\mathrm{NO}_{2}+h v(<410 \mathrm{~nm}) \rightarrow \mathrm{NO}+\mathrm{O}\left({ }^{3} \mathrm{P}\right)$

$\mathrm{HONO}+h v(<390 \mathrm{~nm}) \rightarrow \mathrm{NO}+\mathrm{OH}$ 


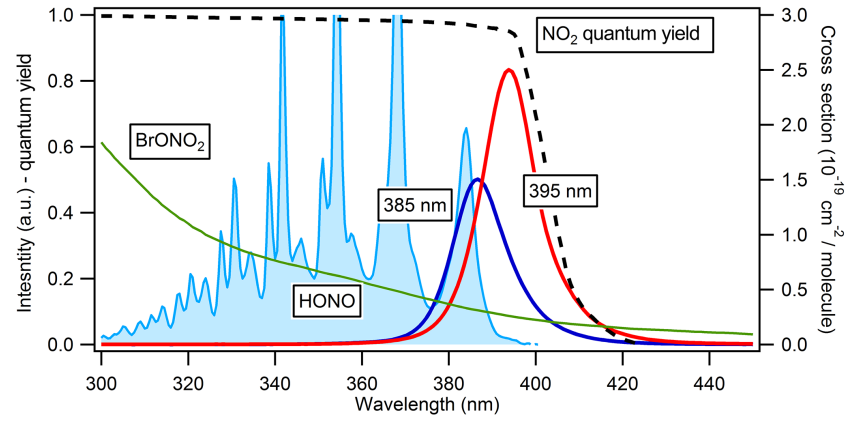

Figure 1. The measured spectral output of two UV-LED elements, nominally $385 \mathrm{~nm}$ output in dark blue and $395 \mathrm{~nm}$ in red. The HONO absorption spectrum is shown in light blue, whilst the $\mathrm{NO}_{2}$ quantum yield is shown in dashed black. The absorption cross section of $\mathrm{BrONO}_{2}$ is shown in green.

The difference in $\mathrm{NO}_{2}^{\dagger}$ signal measured at 385 and $395 \mathrm{~nm}$ corresponds to the difference in conversion efficiency of $\mathrm{HONO}$ and $\mathrm{NO}_{2}$ between the two wavelengths. Differences in $\mathrm{NO}_{2}$ conversion efficiency of each lamp may be readily calibrated for and so taken into account (see Sect. 2.4). The difference in $\mathrm{NO}_{2}^{\dagger}$ signal measured at 385 and $395 \mathrm{~nm}$ can therefore be used to calculate the HONO present in the sample Eq. (1):

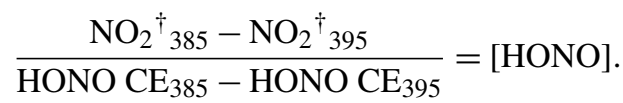

Apparent $\mathrm{HONO}$ conversion efficiency (CE), $\mathrm{HONO} \mathrm{CE}_{385}-$ $\mathrm{HONO} \mathrm{CE}_{395}$, is determined experimentally as described in Sect. 2.4.

\subsection{HONO and $\mathrm{NO}_{2}$ conversion efficiencies}

The $\mathrm{NO}_{2}-\mathrm{HONO}$ converter system was calibrated for both $\mathrm{NO}_{2}$ and HONO conversion efficiency. $\mathrm{NO}_{2}$ conversion efficiencies were determined following the procedure outlined by Lee et al. (2009). Conversion efficiency is the extent to which the equilibrium position of Reactions (R1) and (R2) are to the right. This is dependent on the $j \mathrm{NO}_{2}$ and $j \mathrm{HONO}$ of the UV source, the residence time, and the concentration of oxidants of NO in the photolysis cell as described by Eq. (2) (Ryerson et al., 2000). Here $t$ is the residence time within the photolysis cell, and $k[\mathrm{Ox}]$ is the concentration and rate constant of any oxidant that reacts with NO. Typically this would be ozone; however, $\mathrm{OH}$ formed from HONO photolysis must also be considered.

$\mathrm{CE}=\left[\frac{j t}{j t+k[\mathrm{Ox}] t}\right]\left[1-\exp ^{(-j t-k[\mathrm{Ox}] t)}\right]$

The $\mathrm{NO}+\mathrm{OH}$ back reaction occurs after an air sample has exited the photolytic converter but before entering the high vacuum of the analyser, causing a decrease in signal from HONO as discussed in Sect. 2.5. A similar reaction of
$\mathrm{NO}+\mathrm{O}_{3}$ also occurs; however this is $\sim 3$ orders of magnitude slower than $\mathrm{NO}+\mathrm{OH}$ (Atkinson et al., 2004) and insignificant on the short $(0.11 \mathrm{~s})$ timescale in our instrument.

The sensitivity of a detector in counts per second per part per trillion (cps/ppt) is determined by adding a

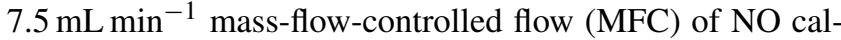
ibration gas (4.78 ppm NO in $\mathrm{N}_{2}, \mathrm{BOC}$ ) to the inlet of the analyser whilst sampling an overflow of zero air free from $\mathrm{NO}_{x}$, VOC, and ozone. This equates to a calibration concentration of $12.5 \mathrm{ppbV}$ NO per channel. Zero air was generated by scrubbing dried $\left(-40 T_{\mathrm{d}}\right)$ compressed air using Sofnofil (Molecular Products) and activated charcoal (Sigma Aldrich) traps. As described by Reed et al. (2016), this combination results in the lowest $\mathrm{NO}_{2}$ signal. The sensitivity was $\sim 6.8$ and $\sim 6.4( \pm 5 \%) \mathrm{cps} / \mathrm{ppt}$ for the $\mathrm{NO}$ and $\mathrm{NO}_{x}$ channels, respectively. In order to determine the $\mathrm{NO}_{2}$ converter efficiency, a portion of the NO added to the inlet is first titrated to $\mathrm{NO}_{2}$ by reaction with ozone, typically generating $10.0 \mathrm{ppbV} \mathrm{NO} \mathrm{N}_{2}$. Ozone is generated by illuminated a small flow $\left(\sim 10 \mathrm{~mL} \mathrm{~min}^{-1}\right)$ of $\mathrm{O}_{2}$ with a broad-output lowpressure mercury UV lamp (BHK Inc.) The analyser signal (photomultiplier counts in $\mathrm{Hz}$ ) is then recorded with neither UV-LED illuminated and then with each illuminated in turn to determine the increase in signal arising for each lamp. The conversion efficiency (CE) is then determined as in Eq. (3), where, when calibrating in zero air or at high mixing ratios relative to the measurement, ambient (Amb) values may be neglected. Ambient signals must be considered when calibration and measurement levels are comparable, and in a changing background.

$\mathrm{CE}=1-$

$\left(\mathrm{NO} . \mathrm{Hz}_{\mathrm{Untitrated}}-\mathrm{NO} \cdot \mathrm{Hz}_{\mathrm{Amb} .1}\right)-\left(\mathrm{NO}_{x} \cdot \mathrm{Hz}_{\text {Illuminated }}-\mathrm{NO}_{x} \cdot \mathrm{Hz}\right.$ Amb $)$

$\left(\mathrm{NO}^{\mathrm{H}} \mathrm{Hz}_{\text {Untitrated }}-\mathrm{NO} . \mathrm{Hz}_{\mathrm{Amb} .2}\right)-\left(\mathrm{NO} \cdot \mathrm{Hz}_{\text {Titrated }}-\mathrm{NO} . \mathrm{Hz} \mathrm{Amb}_{\mathrm{Am} 3}\right)$

The $\mathrm{NO}_{2}$ conversion efficiency was determined to be 72.9 $\left(j=1.3 \mathrm{~s}^{-1}\right)$ and $81.2 \%\left(j=1.7 \mathrm{~s}^{-1}\right) \pm 0.1$ for the 385 and $395 \mathrm{~nm}$ lamps, respectively.

Calibration for HONO was achieved by sampling a permeation source over a range of dilutions using methods modified from Taira and Kanda (1990) and Febo et al. (1995). Nitrous acid was generated by the reaction of hydrochloric acid with sodium nitrite salt as described by Febo et al. (1995), shown in Reaction (R3).

$\mathrm{HCl}+\mathrm{NaNO}_{2} \rightarrow \mathrm{HONO}+\mathrm{NaCl}$

In order to achieve a continuous source of $\mathrm{HONO}$, a permeation tube (Kin-Tek, HRT-010.00-BLANK/U) was filled with $\mathrm{HCl}(37 \%$, Fluka, AR grade) and placed in a thermostated (30 to $55^{\circ} \mathrm{C}$ ) permeation oven (Kin-Tek, 585) with $\mathrm{NaNO}_{2}$ salt (Fluka, AR grade). The permeation oven was flushed with 1.5 standard $\mathrm{L} \mathrm{min}^{-1}$ zero air. The reaction is limited by $\mathrm{HCl}$ which permeates at a low rate thus allowing low concentrations $(<50 \mathrm{ppb})$ of $\mathrm{HONO}$ to be generated continuously.

As side products of Reaction (R3) can also be produced, the output of the permeation source was continuously anal- 
ysed for impurities. In Reaction (R4) $\mathrm{NO}$ and $\mathrm{NO}_{2}$ can be formed by the gas phase self-reaction of HONO. In Reaction (R5), $\mathrm{HNO}_{3}$ can be formed by reaction between adsorbed and gas phase HONO.

$$
\begin{aligned}
& 2 \mathrm{HONO}_{(\mathrm{g})} \rightarrow \mathrm{NO}+\mathrm{NO}_{2}+\mathrm{H}_{2} \mathrm{O} \\
& \mathrm{HONO}_{(\mathrm{ads})}+\mathrm{NO}_{2} \rightarrow \mathrm{HNO}_{3}+\mathrm{NO}
\end{aligned}
$$

To quantify HONO without any direct measurement and close the nitrogen balance, $\mathrm{NO}, \mathrm{NO}_{2}$, and total $\mathrm{NO}_{y}$ $\left(\mathrm{NO}+\mathrm{NO}_{2}+\right.$ other reactive oxidized nitrogen species such as $\mathrm{HNO}_{3}, \mathrm{HONO}, \mathrm{PAN}$ ) were measured continuously. The differential photolysis instrument itself was used to quantify the $\mathrm{NO} . \mathrm{NO}_{2}$ was measured directly using an EPA certified Teledyne API T500U which uses Cavity Attenuated Phase Shift (CAPS) spectroscopy from Aerodyne Research Inc. (Kebabian and Freedman, 2007; Kebabian et al., 2005, 2008), to avoid any HONO interference which would have been present in a photolytic measurement. This is because the T500U uses a $450 \mathrm{~nm}$ band-pass for $\mathrm{NO}_{2}$, whereas $\mathrm{HONO}$ absorbs only below $390 \mathrm{~nm}$ as shown in Fig. 1. Glyoxal is a possible interference in the CAPS technique as it also absorbs in the 440-460 $\mathrm{nm}$ range (Volkamer et al., 2005), however all VOC are scrubbed from the zero air during calibration. The nitrate radical (from particulate nitrate) is also an interference in the CAPS technique as it absorbs above $\sim 400 \mathrm{~nm}$ (Stark et al., 2007), however the T500U is fitted with a high-efficiency particulate air (HEPA) filter to mitigate this. Nitric acid which absorbs below $340 \mathrm{~nm}$ (Rattigan et al., 1992) is also not an interference. Total $\mathrm{NO}_{y}$ was quantified using a Thermo Environmental 42c $\mathrm{TL} \mathrm{NO}_{x}$ analyser equipped with a molybdenum catalytic converter which has been shown to quantify $\mathrm{NO}_{y}$ species such as HONO and $\mathrm{HNO}_{3}$ (Clemitshaw, 2004; Fehsenfeld et al., 1987; Villena et al., 2012; Williams et al., 1998). The TEI 42c TL and Teledyne API T500U were calibrated either directly with an $\mathrm{NO}$ standard or by gas phase titration of $\mathrm{NO}$ to $\mathrm{NO}_{2}$ using a Monitor Europe S6100 Multi Gas Calibrator. Production of $\mathrm{HNO}_{3}$ (Reaction R5) would be indicated by an enhancement in $\mathrm{NO}$ over $\mathrm{NO}_{2}$, as $\mathrm{NO}$ and $\mathrm{NO}_{2}$ are produced stoichiometrically through the self-reaction of HONO (Reaction R4), whereas $\mathrm{HNO}_{3}$ production consumes $\mathrm{NO}_{2}$ and produces NO. Thus, $\mathrm{HNO}_{3}$ can be indirectly quantified by the $\mathrm{NO}: \mathrm{NO}_{2}$ ratio, and was found to be a minimal contribution to total $\mathrm{NO}_{y}$. As such, $\mathrm{HONO}$ can reasonably be presumed to be equivalent to $\left[\mathrm{NO}_{y}\right]-\left([\mathrm{NO}]+\left[\mathrm{NO}_{2}\right]+\left[\mathrm{HNO}_{3}\right]\right)$. Measured quantities are shown in Table 1.

The stability of the HONO permeation source was recorded over a $12 \mathrm{~h}$ period using $\mathrm{NO}_{x}$ measured by the differential photolysis analyser (the most sensitive measurement available) as a proxy for $\mathrm{NO}, \mathrm{NO}_{2}$, and $\mathrm{HONO}$. The stability was found to be $\pm 0.01 \mathrm{ppbh}^{-1}$, with a standard deviation of $0.4 \mathrm{ppb}$. The uncertainty in the HONO source is determined by a combination of the accuracy of the NO, $\mathrm{NO}_{2}$, and $\mathrm{NO}_{y}$ measurements and their respective calibra-

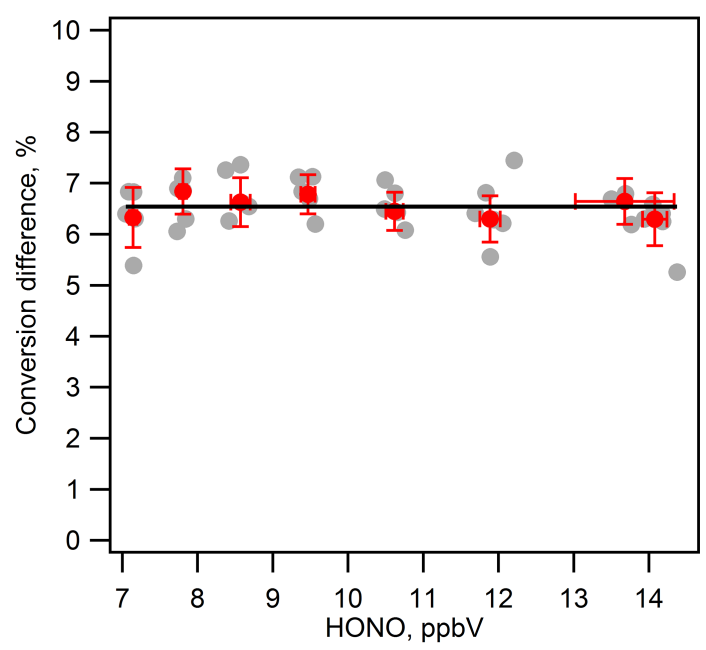

Figure 2. Difference in HONO conversion between 385 and $395 \mathrm{~nm}$ UV-LEDs over a range of dilutions. Median values are in red, whilst all data are shown in grey. Linear fit is in black; error bars show standard deviation of the mean values.

tions. The NO calibration uncertainty, due to MFC flows and standard gas accuracy is $5 \%$, similarly for the CAPS $\mathrm{NO}_{2}$ and Thermo 42i TL $\mathrm{NO}_{y}$. This results in an overall uncertainty in [HONO] of $8.7 \%$.

In Fig. 2 the observed conversion of HONO, that is the difference between HONO conversion by the 385 and $395 \mathrm{~nm}$ lamps, is shown. As can be seen HONO conversion is consistently $6.54 \pm 0.21 \%$ more at $385 \mathrm{~nm}$ than $395 \mathrm{~nm}$. The fact that the "apparent $\mathrm{HONO}$ conversion" (HONO $\mathrm{CE}_{385}$ $-\mathrm{HONO} \mathrm{CE}_{395}$ in Eq. 1) is constant as a function of $\mathrm{HONO}$ means that the determination of [HONO] should be a linear function of the difference in $\mathrm{NO}_{2}^{\dagger}$ signal at 385 and $395 \mathrm{~nm}$.

\subsection{Measurement precision and limit of detection}

The precision of NO chemiluminescence detection is the ability to discriminate signal from photon counting noise. The photon counting noise is taken as the standard deviation of the pre-chamber zero signal (determined every $5 \mathrm{~min}$ as described in Sect. 2.1) in $\mathrm{Hz}$ (counts per second) di-

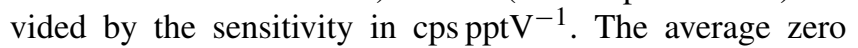
count rate was $\sim 3000 \mathrm{~Hz}$ on both channels with a $1 \sigma$ standard deviation of $\sim 75 \mathrm{~Hz}$, giving a precision for $\mathrm{NO}$ of 11.0 and $11.7 \mathrm{pptV}$ for $1 \mathrm{~s}$ data with sensitivities of 6.8 and $6.4 \mathrm{cps} \mathrm{pptV}^{-1}$ for channels 1 and 2 , respectively. The precision for $\mathrm{NO}_{2}$ and $\mathrm{HONO}$ (channel 2) must be divided by their conversion efficiencies. This results in a precision for $\mathrm{NO}_{2}$ of 16.0 and $14.4 \mathrm{pptV}$ for $1 \mathrm{~s}$ data at 385 and $395 \mathrm{~nm}$, respectively. The HONO precision is calculated from the (constant) differential conversion efficiency as $179.9 \mathrm{pptV}$ for $1 \mathrm{~s}$ data.

The limit of detection is defined as the precision multiplied by $1 / \sqrt{ } n$, where $n$ is the number of data points (Lee et al., 2009). For $1 \mathrm{~min}$ data the LOD for NO is $1.4 \mathrm{pptV}$. As the 
Table 1. Showing the distribution of $\mathrm{NO}_{y}$ species $\mathrm{NO}, \mathrm{NO}_{2}, \mathrm{HNO}_{3}$, and $\mathrm{HONO}$ produced from the HONO permeation source.

\begin{tabular}{lrrrrr}
\hline No. & $\begin{array}{r}\mathrm{NO}_{y} \mathrm{ppb} \\
\text { measured }\end{array}$ & $\begin{array}{r}\mathrm{NO} \mathrm{ppb} \\
\text { measured }\end{array}$ & $\begin{array}{r}\mathrm{NO}_{2} \mathrm{ppb} \\
\text { measured }\end{array}$ & $\begin{array}{r}\mathrm{HNO}_{3} \mathrm{ppb} \\
\text { calculated }\end{array}$ & $\begin{array}{r}\mathrm{HONO} \mathrm{ppb} \\
\text { calculated }\end{array}$ \\
\hline 1 & 20.40 & 3.34 & 2.64 & 0.35 & 14.08 \\
2 & 19.29 & 2.96 & 2.35 & 0.30 & 13.68 \\
3 & 16.82 & 2.59 & 2.10 & 0.26 & 11.89 \\
4 & 14.95 & 2.27 & 1.87 & 0.20 & 10.62 \\
5 & 13.40 & 2.05 & 1.73 & 0.16 & 9.45 \\
6 & 12.15 & 1.86 & 1.58 & 0.14 & 8.57 \\
7 & 11.09 & 1.70 & 1.46 & 0.12 & 7.81 \\
8 & 10.17 & 1.60 & 1.35 & 0.11 & 7.14 \\
\hline Percent & - & 15.5 & 12.8 & 1.3 & 70.4 \\
\hline
\end{tabular}

$\mathrm{NO}_{x}$ channel operates on a $30 \mathrm{~s}$ switching cycle, the $1 \mathrm{~min}$ data are actually only averaged over $30 \mathrm{~s}$. Thus, the $1 \mathrm{~min}$ $\mathrm{NO}_{2}$ limit of detection is $2.6 \mathrm{pptV}$ (calculated from the CE of the $395 \mathrm{~nm}$ lamp), and the limit of detection of HONO is $32.8 \mathrm{pptV}$ averaged over $1 \mathrm{~min}$. However the HONO limit of detection must also account for the $\mathrm{NO}_{2}$ limit of detection at both 385 and $395 \mathrm{~nm}$, resulting in an overall HONO LOD of $38.3 \mathrm{pptV}$ averaged over $1 \mathrm{~min}$.

\subsection{Measurement artefacts, interferences, and uncertainties}

It is noted that at both 385 and $395 \mathrm{~nm}$ there is potential photolytic interference from $\mathrm{BrONO}_{2}$ (or in fact any other compounds which photolyse to give NO at either wavelength), with similar spectral overlap (Fig. 1). Assuming a quantum yield of 1 integrated over all wavelengths for $\mathrm{BrONO}_{2}$, $21.5 \mathrm{ppt}$ of $\mathrm{BrONO}_{2}$ at $385 \mathrm{~nm}$ and $18.1 \mathrm{ppt}$ at $395 \mathrm{~nm}$ would be required to produce a $1 \mathrm{ppt}$ error in the $\mathrm{NO}_{2}-\mathrm{HONO}$ signal. Due to the low abundance $(<10 \mathrm{pptV})$ of $\mathrm{BrONO}_{2}$ in the lower atmosphere (Yang et al., 2005), interference is therefore likely to be minimal (Pollack et al., 2011). The difference in conversion for the different lamps equates to a maximum error in $\mathrm{HONO}$ determination of $3.4 \%\left[\mathrm{BrONO}_{2}\right]$ : typically much less than $1 \mathrm{pptV}$.

Thermal interferences can also become apparent if the photolytic converter raises the temperature of the sample gas above ambient (Reed et al., 2016). Thermally labile $\mathrm{NO}_{y}$ compounds, e.g. peroxyacetyl nitrate, may decompose within the converter, resulting in a positive signal when measuring in $\mathrm{NO}_{x}$ mode. This will be true at either 385 or $395 \mathrm{~nm}$ wavelengths. Under the reasonable assumption that the temperature of the photolysis cell is the same at both wavelengths, then, as shown in our previous work (Reed et al., 2016), the interference scales with $\mathrm{NO}_{2}$ conversion efficiency. In this case the difference in thermal interference at $385 \mathrm{~nm}$ is $10.2 \%$ greater than at $395 \mathrm{~nm}$ owing to having a lower $\mathrm{NO}_{2}$ conversion efficiency. This represents a small bias in the HONO measurement, which can be eliminated by hav- ing $\mathrm{NO}_{2}$ conversion efficiencies equal at both wavelengths as was the case during field measurements in Sect. 3.2. When $\mathrm{NO}_{2}$ conversion efficiencies are equal, thermal interferences affect only the $\mathrm{NO}_{2}$ measurement; when they are unequal, some uncertainty proportional to the difference in $\mathrm{NO}_{2} \mathrm{CE}$ is introduced.

Zero offset artefacts have been shown to manifest in photolytic converters (Gao et al., 1994; Del Negro et al., 1999; Pollack et al., 2011; Ryerson et al., 2000). That is, when sampling $\mathrm{NO}_{x}$-free synthetic air, a non-zero signal is observed when the photolytic converter is illuminated. This is attributed to $\mathrm{NO}_{x}$ production from species adsorbed on the walls of the photolytic converter once illuminated by UV (Pollack et al., 2011). These artefacts were accounted for during calibration by sampling an overflow of $\mathrm{NO}_{x}$-free zero air whilst recording the analyser signal when the photolysis cell was illuminated at 385 and $395 \mathrm{~nm}$. The artefacts were found to be 368 and $319( \pm 5 \%)$ pptV, respectively. There was $0 \mathrm{pptV}$ artefact in NO. UV-induced artefacts vary with time (Ryerson et al., 2000) and have intrinsic uncertainty in their determination; they thus contribute to overall measurement uncertainty.

This spurious artefact signal can be minimized by periodic cleaning of the inside of the photolysis cell (Pollack et al., 2011; Reed et al., 2016; Ryerson et al., 2000), by choice of cell material (Reed et al., 2016), and by lensing the UV light so as not to illuminate the walls of the cell - sacrificing some conversion efficiency (Ridley et al., 1988).

The effect of the back reaction of $\mathrm{OH}+\mathrm{NO}$ to reform HONO before detection of NO, thus reducing the NO signal in the $\mathrm{NO}_{x}-\mathrm{HONO}$ measurement in the presence of HONO, is another possible source of uncertainty. As a greater proportion of HONO is photolysed at one wavelength respective to another, the sample inside and exiting the converter necessarily has differing $\mathrm{OH}$ concentrations. The effect on the NO signal detected was calculated using a box model in FACSIMILE kinetic modelling software (MCPA Software Ltd.). Kinetic data for $\mathrm{O}_{x}, \mathrm{HO}_{x}$, and $\mathrm{NO}_{x}$ reactions are taken from IUPAC Evaluated Kinetic Data (Atkinson et al., 2004). 
The box model was initiated with the $\mathrm{NO}, \mathrm{NO}_{2} \mathrm{HONO}$, and $\mathrm{HNO}_{3}$ concentrations shown in Table 1. NO, $\mathrm{NO}_{2}, \mathrm{O}_{3}$, and $\mathrm{OH}$ concentrations at the outlet of the photolysis cell after $1 \mathrm{~s}$ illumination at each wavelength were calculated. The residence time between an air sample exiting the photolysis cell and entering the high vacuum of the NO analyser through the $\sim 25 \mathrm{~cm}$ of $1 / 4 \mathrm{in}$. PFA tubing is $0.11 \mathrm{~s}$. The air sample is a mixture of mostly $\mathrm{NO}, \mathrm{O}_{3}, \mathrm{OH}$, and unconverted $\mathrm{NO}_{2}$. The absence of UV irradiation results in chemistry analogous to night-time $\mathrm{NO}_{x}$ chemistry with the addition of a significant $\mathrm{OH}$ source. The interference from the $\mathrm{OH}+\mathrm{NO}$ reaction was determined as the decrease in [NO] during the $0.11 \mathrm{~s}$ residence time as a percentage of measured [HONO]. The discrepancy was calculated to vary linearly with [HONO] from -0.97 to $-2.10 \%$ over the range of calibrations, with differences between lamps well within the accuracy of the calibration. The degree of interference from $\mathrm{OH}$ in $\mathrm{NO}_{2}$ and $\mathrm{HONO}$ determination was found to be a function of $k([\mathrm{OH}]+[\mathrm{NO}])$ on the timescale here $(0.11 \mathrm{~s})$. Reducing the residence time after the photolysis cell would reduce the error in HONO and $\mathrm{NO}_{2}$ (in the presence of HONO). Conversely, a system with a suitably long residence time between the photolysis cell and detector may experience little-to-no HONO interference as the $\mathrm{OH}+\mathrm{NO}$ back reaction begins to dominate. There is of course a trade-off in that the data must be corrected for ambient ozone affecting the $\mathrm{NO}: \mathrm{NO}_{2}$ ratio. It is important to note that there can never be any negative interference in $\mathrm{NO}_{2}$ caused by the presence of HONO, only positive or none.

Outside of calibration the effect of the $\mathrm{OH}$ back reaction with $\mathrm{NO}$ is likely to be less significant due to the presence of volatile organic compounds (VOCs) which also react with $\mathrm{OH}$ with comparable rates to NO. It is therefore difficult to know the absolute HONO conversion of each UV-LED without very accurate $\mathrm{OH}$ reactivity/VOC concentration measurements. Due to these unknowns, it would not be possible to correct the $\mathrm{NO}_{2}$ signal for $\mathrm{HONO}$ interference as might be hoped.

Additional uncertainties arise in the HONO measurement from sampling a changing $\mathrm{NO}_{2}^{\dagger}$ background. Changes in signal when illuminating a sample at $385 \mathrm{~nm}$ cannot be attributed to $\mathrm{NO}_{2}$ or HONO without also knowing the corresponding signal at $395 \mathrm{~nm}$ which necessarily is measured at a different time. This uncertainty can be reduced by increasing the differential conversion (which was $6.54 \%$ in our system). We make the first order assumption that the $\mathrm{NO}_{2}$ or $\mathrm{HONO}$ background changes on slower timescales than the instrument response, and that it does not change over the course of two $30 \mathrm{~s}$ cycles.

Thus, the uncertainty in the differential conversion is a combination of the uncertainty in the HONO calibration source $(8.7 \%)$, the uncertainty of the sensitivities $(5 \%)$, $\mathrm{NO}_{2}$, and HONO conversion efficiencies (5\%), and the uncertainty in the artefact $(5 \%)$. This results in an overall root sum of squares uncertainty of $15.8 \%$ in [HONO].

\section{Results and discussion}

The pHONO instrument was evaluated in an atmospheric simulation chamber (Sect. 3.1) and compared in the field side by side with LOPAP (Sect. 3.2).

\subsection{Chamber measurements}

The Highly Instrumented Reactor for Atmospheric Chemistry (HIRAC) is a simulation chamber facility based at the School of Chemistry, University of Leeds (Glowacki et al., 2007a). HIRAC is a cylindrical stainless-steel chamber with a total volume of $\sim 2.25 \mathrm{~m}^{3}$, containing four fans for mixing throughout the chamber, and with a total mixing time of $\sim 60 \mathrm{~s}$. The stainless-steel structure of HIRAC allows for pressure-dependent experiments to be carried out, over the range of $\sim 10-1000$ mbar. Numerous sample ports are located around the chamber allowing the attaching of instruments or introduction of gas. A multi-pass Fourier transform infrared (FT-IR) instrument (Bruker IFS/66, $128.52 \mathrm{~m}$ path length) is present to allow spectra of the gas within the chamber to be taken (Glowacki et al., 2007b). HIRAC is also capable of operating over a range of temperatures $\left(-40\right.$ to $\left.70^{\circ} \mathrm{C}\right)$.

Experiments were carried out at ambient temperature $\left(20^{\circ} \mathrm{C}\right)$ and pressure $(1000 \mathrm{mbar})$, whilst the chamber was kept dark. HIRAC was filled with $80 \% \mathrm{~N}_{2}$ (BOC, UHP, $99.998 \%$ ) and $20 \% \mathrm{O}_{2}$ (BOC) before HONO was synthesized external to the chamber following a modified procedure described previously by Taira and Kanda (1990). A $1 \%$ aqueous sodium nitrite solution was added dropwise to a $30 \%$ aqueous solution of sulfuric acid. The resulting Reaction (R6) produces HONO, which was added directly to the chamber via a continuous flow of $\mathrm{N}_{2}$ over the reaction mixture. This is analogous to the permeation source; however, side products need not be considered due to the direct HONO measurement afforded by FT-IR.

$2 \mathrm{NaNO}_{2}+\mathrm{H}_{2} \mathrm{SO}_{4} \rightarrow 2 \mathrm{HONO}+\mathrm{Na}_{2} \mathrm{HSO}_{4}$

FT-IR spectra were taken at $60 \mathrm{~s}$ intervals with a spectral resolution of $1 \mathrm{~cm}^{-1}$, whilst the differential photolysis analyser sampled from the chamber. Dilution of the HONO$\mathrm{NO}-\mathrm{NO}_{2}$ mixture was achieved by partial evacuation of the chamber and subsequent refilling with synthetic air $\left(\mathrm{N}_{2} / \mathrm{O}_{2}\right)$. The average HONO concentration determined from the average of two distinct absorbance lines at $1264 \mathrm{~cm}^{-1}$ (trans-HONO, Q-branch) and $853 \mathrm{~cm}^{-1}$ (cis-HONO, Q-branch) in the FT-IR using absolute line strength data from Barney et al. (2000). The absorptivity data were $5.22 \pm 0.52 \times 10^{-19} \mathrm{~cm}^{2}$ molecule ${ }^{-1}\left(1264 \mathrm{~cm}^{-1}\right.$, trans-HONO) and $9.00 \pm 0.90 \times 10^{-19} \mathrm{~cm}^{2}$ molecule $^{-1}$ $\left(853 \mathrm{~cm}^{-1}\right.$, cis-HONO). Barney et al. (2000) showed there to be discrepancies between various published line strengths, as did Lee et al. (2012); thus there is some inherent uncertainty in the absolute [HONO] determined by FT-IR. Some of the spectra used in quantification are shown in Fig. 3. 


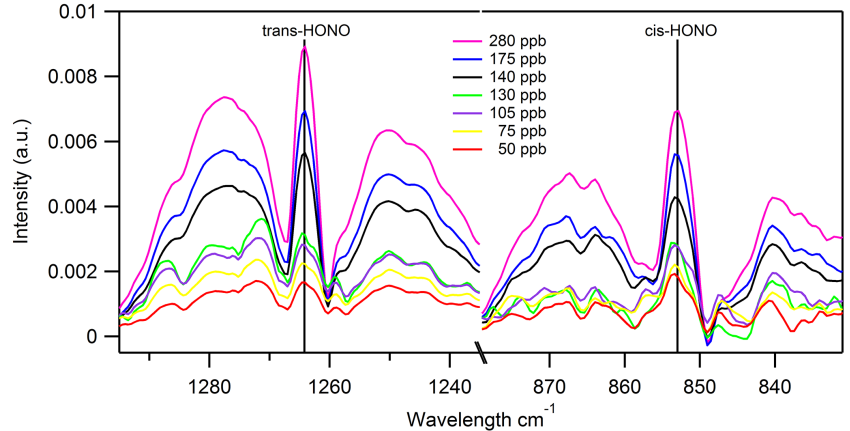

Figure 3. FT-IR spectra of dominant HONO absorbance lines at 1264 and $853 \mathrm{~cm}^{-1}$ over a range of concentrations.

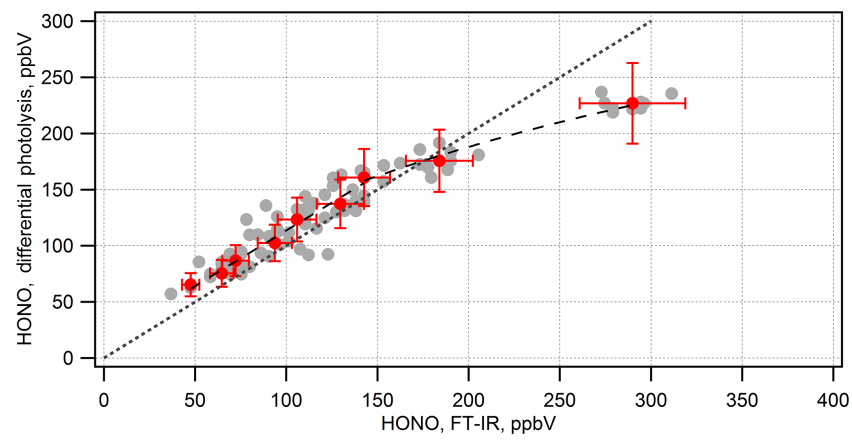

Figure 4. HONO determined by FT-IR ( $y$ axis) versus HONO measured by the photolytic/chemiluminescence differential photolysis instrument ( $x$ axis). Median values at each dilution are in red; all values are shown in grey. The $1: 1$ line is shown for reference as well as an exponential fit above $140 \mathrm{ppbV}$ HONO. Error bars show the $15.8 \%$ calibration uncertainty of the $\mathrm{pHONO}$ instrument and the $10.0 \%$ uncertainty in the FT-IR cross section (Barney et al., 2000).

Figure 4 shows the strong positive correlation between the HONO measured by differential photolysis and by FT-IR within the HIRAC chamber up to $\sim 140 \mathrm{ppbV}$, deviating at higher mixing ratios. Systematic offset between the pHONO and FT-IR can be attributed to uncertainties in the FT-IR line strength data for HONO and the uncertainty in the pHONO calibration as indicated by the $x(15.8 \%)$ and $y(10.0 \%)$ error bars. However, the data lie close to or on the $1: 1$ correlation line when these uncertainties are included. Studies have also shown there to be large discrepancies between different published line strengths for HONO (Barney et al., 2000; Lee et al., 2012), which constitutes a greater uncertainty in [HONO] derived by FT-IR of up to $+33 \%$ and -25 to $-30 \%$ (Barney et al., 2000) depending on the particular cross section used.

Figure 4 shows that at lower HONO mixing ratios, $<140 \mathrm{ppb}$, there is better agreement between the pHONO and FT-IR measurements, whereas the response of the differential photolysis technique appears to be suppressed at high

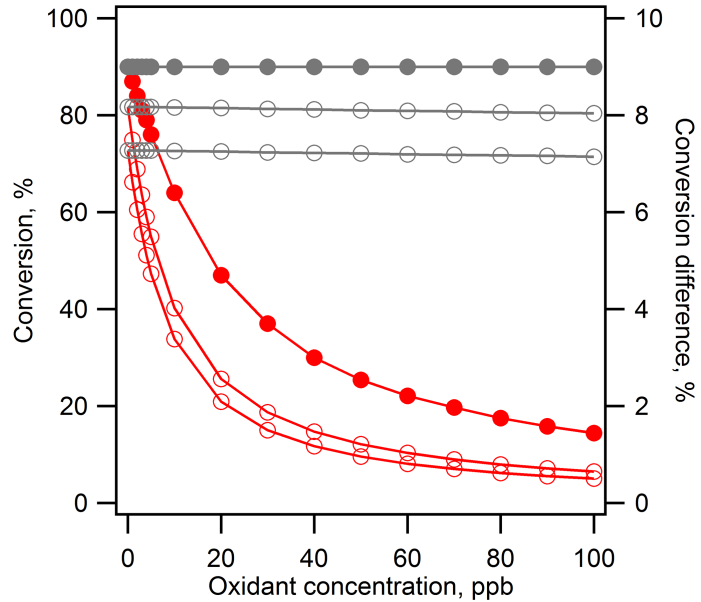

Figure 5. Simulated conversion (open circles) and difference in conversion (closed circles) for photolytic converters with different $j$ in the presence of $\mathrm{OH}$ (red) and $\mathrm{O}_{3}$ (grey) oxidants.

[HONO]. This is a result of how a photolytic converter operates as expressed by Eq. (2) in Sect. 2.4

Having two LEDs with different HONO absorption overlap results in two values for $j(\mathrm{HONO})$. Using the $j\left(\mathrm{NO}_{2}\right)$ values already found $\left(1.3\right.$ and $\left.1.7 \mathrm{~s}^{-1}\right)$ as an easily determined proxy for $j(\mathrm{HONO})$, the change in conversion with oxidant concentration can be approximated.

Figure 5 shows how the percentage conversion of any precursor that dissociates to $\mathrm{NO}$, in this case $\mathrm{HONO}$ and $\mathrm{NO}_{2}$, changes with increasing oxidant concentration. In the case of $\mathrm{O}_{3}$ the total conversion decreases linearly with increasing [Ox], whilst the difference between the two remains constant $(9 \%)$. Conversely, with $\mathrm{OH}$, conversion decays exponentially in total, and as a difference between two LEDs of different $j$. This effect can be seen clearly above $150 \mathrm{ppbV}$ HONO in Fig. 4. Below $140 \mathrm{ppbV}$ a constant difference in conversion of $6.54 \%$ is a reasonable approximation.

The high HONO mixing ratios within HIRAC, necessary to be detected by FT-IR (LOD $\sim 40 \mathrm{ppb}$ ), were several orders of magnitude higher than would be expected in the atmosphere where ppt (Beine et al., 2006; Ren et al., 2010; Zhang et al., 2009, 2012) to low ppb (Acker et al., 2006; Febo et al., 1996; Hendrick et al., 2014; Kanaya et al., 2007; Stutz, $2004)$ are typical. Thus, this non-linearity at high [HONO] is unlikely to pose a serious limitation of the differential photolysis method, with the possible exception of areas with very high $\mathrm{NO}_{x}$ backgrounds. This could be partially mitigated by having greater photolysis power at $385 \mathrm{~nm}$, in combination with moving to shorter wavelengths with better overlap with the HONO absorption cross section. It is clear in Fig. 1 that the $385 \mathrm{~nm}$ UV-LED has significantly lower light output than at $395 \mathrm{~nm}$; this is reflected in their respective $\mathrm{NO}_{2}$ conversion efficiencies (72.9 and $81.3 \%$ ). Alternatively, separate 385 and $395 \mathrm{~nm}$ converters can be employed working in paral- 
lel, thus doubling the number of UV-LEDs and doubling the photolysis power at each respective wavelength. This would also allow for fast measurement simultaneously, i.e. $1 \mathrm{~Hz}$ or faster. Alternatively, the lower conversion efficiency at high [HONO] could be calibrated for, though, as shown in the following section, in typical atmospheric conditions no calibration or correction was required.

\subsection{Field measurements}

The Weybourne Atmospheric Observatory (WAO; Penkett et al., 1999) is a regional Global Atmosphere Watch (GAW) station located on the North Norfolk coast, UK $\left(52^{\circ} 57^{\prime} 01.5^{\prime \prime} \mathrm{N} 1^{\circ} 07^{\prime} 19^{\prime \prime} \mathrm{E}\right)$. The WAO has a long history of atmospheric measurements stretching back to its inception in 1994. During summer 2015, the WAO was host to the Integrated Chemistry of Ozone in the Atmosphere (ICOZA) campaign, ostensibly measuring ozone production rates. As part of the campaign a long path absorption photometer (LOPAP-03, QUMA Elektronik \& Analytik GmbH) (Heland et al., 2001) was deployed in order to measure HONO. Alongside the LOPAP, the $\mathrm{NO}, \mathrm{NO}_{2}, \mathrm{HONO}$ (differential photolysis) instrument described in Sect. 2.1 measured at a 1 min time resolution.

During the ICOZA campaign, a high variation of HONO concentrations (up to $\sim 500 \mathrm{pptV}$ ) were observed by the LOPAP between 29 June and 7 July, providing an ideal opportunity for comparison between the two methods. The pHONO was deployed with replacement UV-LEDs with greater output. Both the 385 and $395 \mathrm{~nm}$ lamps had the same photon flux, indicated by identical individual $\mathrm{NO}_{2}$ conversion efficiencies $(\sim 89 \%)$, in the expectation that better HONO conversion, and therefore sensitivity, would be achieved. The estimated increase in overlap with the HONO adsorption spectrum of the new $385 \mathrm{~nm}$ LED was $45 \%$, compared to $30 \%$ calculated for the original LED. Thus lamps were installed as is without calibration to mitigate the fall in output over time that affects the LEDs, particularly the $385 \mathrm{~nm}$ LED. The decreasing output is believed to be a result of the power control circuitry of the LEDs which does not limit the current draw immediately after power is supplied, only after a few seconds. This means every time the lamp is switched on it outputs its maximum (with corresponding heat), which, when used in a $30 \mathrm{~s}^{-1}$ switching mode as here, shortens the life considerably.

The pHONO instrument sampled from an inlet box (also housing a $\mathrm{NO}_{y}$ converter) located $\sim 4 \mathrm{~m}$ from ground level on the sampling tower at Weybourne. The sample point was connected to the instrument by a $12 \mathrm{~m} 1 / 4$ in. PFA line (Swagelok) which was shared by the CAPS $\mathrm{NO}_{2}$ instrument; thus the flow rate was $\sim 3$ standard $\mathrm{L} \mathrm{min}^{-1}$, resulting in a residence time of $\sim 3 \mathrm{~s}$. The LOPAP instrument, which has its own inlet, sampled from the roof of a specially converted van located $20 \mathrm{~m}$ away upslope. Consequently, both instruments sampled at a similar height and there was clear, unob-

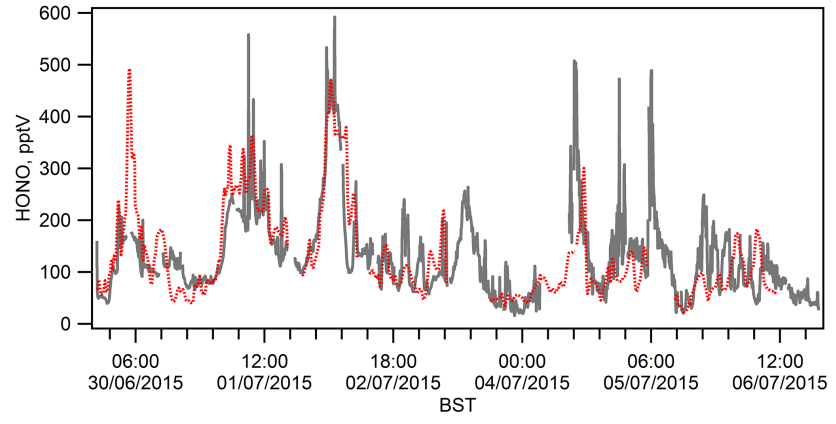

Figure 6. HONO time series during July 2015 at the Weybourne Atmospheric Observatory (WAO) measured by LOPAP (grey) and pHONO (red).

structed line of sight between them. The pHONO inlet was only $\sim 1 \mathrm{~m}$ above the Weybourne observatory roof, which may have contributed to the turbulent dynamics observed in the data especially during daytime. The pHONO instrument was calibrated for NO sensitivity in ambient air twice nightly at 00:00 and 04:00 LT; NO offset was taken between these times by assuming it is equivalent to a stable night-time NO value in remote regions away from any source, where NO should be zero in the presence of ozone (Lee et al., 2009). $\mathrm{NO}_{2}$ conversion efficiencies were determined in zero air once per week. Limits of detection were 1.5 and $1.9 \mathrm{ppt}$ averaged over 1 min for $\mathrm{NO}$ and $\mathrm{NO}_{2}$, respectively. The LOPAP was operated and calibrated according to the standard procedures described in Kleffmann and Wiesen (2008), with a detection limit of $3 \mathrm{pptV}$ and time resolution of $5 \mathrm{~min}$. Zero measurements using high-purity $\mathrm{N}_{2}$ ( $\mathrm{N} 5$ grade, $\mathrm{BOC}$ ) were performed every $12 \mathrm{~h}$ on the LOPAP.

Figure 6 shows the HONO time series from both the LOPAP and pHONO instruments during the 8 days of concurrent HONO measurements.

There is reasonable agreement $\left(R^{2}=0.58, y=0.82 x\right)$ between the established LOPAP method of HONO measurement and that provided by the pHONO instrument without correction or calibration (Fig. 6). During the high-ozone and high-HONO events observed on the first and second especially there is very good agreement $\left(R^{2}=0.70, y=0.83 x\right)$ between the two. Gaps in the data represent times where the pHONO limit of determination was reached - where there are too few points in the averaging window after statistical analysis of the data to be meaningful, e.g. $<2$ points in a 5 min averaging window. This is because in real atmospheric conditions the pHONO instrument is hampered by the time resolution at which data are collected; i.e. if there is strong turbulence, meaning the $\mathrm{NO}_{2}$ or $\mathrm{HONO}$ concentration varies rapidly on a timescale shorter than that at which data are collected, then wide scatter is observed as was the case at Weybourne. Strong boundary layer transport meant that the $\mathrm{NO}_{2}$ measurement varied by up to $1.5 \mathrm{ppb}$ in a minute; this was most evident during the mornings. The limitation is because 
of the way the data must be processed by interpolating between measurements and subtraction of the $395 \mathrm{~nm}$ signal form the $385 \mathrm{~nm}$ signal. Decreasing the time between photolysis switching (from $30 \mathrm{~s}$ ) would obviously decrease this effect, but, ultimately, separate $385 \mathrm{~nm}$ (or lower) and $395 \mathrm{~nm}$ analyser channels are required. Consequently the data analysis routine for the $\mathrm{pHONO}$ data includes tests for the variability of the data, discarding points which show $>5 \%$ variation from the subsequent point. Data failing this test are discarded and result in gaps; this is the effective limit of determination. The data are then treated with a robust locally weighted scatter plot smoothing (LOESS; Cleveland, 1979) algorithm to remove extreme values. The gaps in the time series of LOPAP (Fig. 5) were due to the removal of zero measurements and false spikes due to bubbles passing the detector.

Figure 7 demonstrates the level of agreement in the measured HONO concentration by the LOPAP and pHONO methods from 29 June and 7 July. In Fig. 7, the data have been fitted by orthogonal distance regression (Boggs et al., 1987), which allows for errors in both $x$ and $y$ data but which has been shown to possibly overestimate the slope (Carroll and Ruppert, 1996), and by simple linear regression. In either case a strong positive correlation is exhibited, suggesting the replacement UV-LEDs had the desired effect without the application of corrections for the HONO conversion efficiency. The slopes of 0.82 and 1.02 suggest that the new $385 \mathrm{~nm}$ lamp was able to convert the majority of HONO. The discrepancy suggests that up to $\sim 18 \%$ of $\mathrm{HONO}$ was converted by the $395 \mathrm{~nm}$ lamp. The scatter evident in Fig. 7 is attributed to atmospheric dynamic effects resulting in a rapidly changing $\mathrm{NO}_{2}$ background on timescales faster than the response of the instrument $\left(30 \mathrm{~s}^{-1}\right)$, leading to a coefficient of determination of 0.58. Non-zero intercepts indicate a small systematic offset may be present in the pHONO instrument, though more likely is an effect of scatter on the regressions. Disagreement between the two methods (e.g. 29 June) is likely due to local contamination from diesel-powered agricultural and construction equipment operating nearby, and by the exhaust of the fluorescence assay by gas expansion (FAGE) instrument (Whalley et al., 2013). The FAGE can discriminate $\mathrm{HO}_{2}$ and $\mathrm{RO}_{2}$ by complete reaction of $\mathrm{HO}_{2}$, with $\mathrm{NO}$ necessitating high NO concentrations. The exhaust is vented through a vat of Sofnofil sorbent which removes most $\mathrm{NO}_{x}$ but may also oxidize NO to HONO, which then may be sampled differently by the pHONO instrument and LOPAP due to their relative locations to the FAGE exhaust.

Accuracy and uncertainty in unstable conditions could be improved by measuring at the two different wavelengths concurrently, rather than consecutively. In the same way photolytic $\mathrm{NO}_{2}$ measurement is improved by measuring concurrently with NO, rather than consecutively. This would require three chemiluminescent analysers in parallel, with two photolytic converters. However, in ambient indoor air quality monitoring, where HONO is seen as increasingly im-

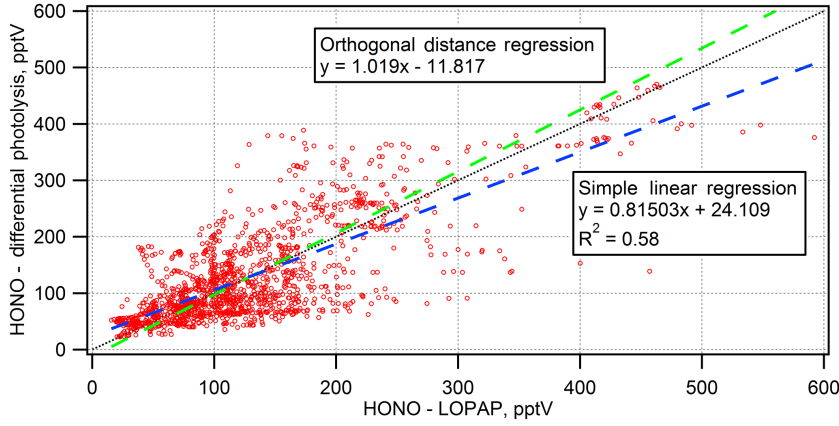

Figure 7. Correlation between HONO measured by LOPAP ( $x$ axis) and pHONO ( $y$ axis). The simple linear regression is shown in blue, and the orthogonal distance regression in green. The $1: 1$ line is shown for reference.

portant (Gligorovski, 2016), a simple single-channel, dualwavelength design might be appropriate and useful.

\section{Conclusions}

An instrument for in situ determination of HONO photolytically has been developed, characterized, and deployed in the field as a proof of concept. During an atmospheric simulation chamber comparison, the HONO measured corresponded well with FT-IR measurement. During field tests the photolytic HONO instrument agreed reasonably $\left(R^{2}=0.58\right.$, $y=0.82 x$ ) well with the established LOPAP instrument, though the limitations of having a two-channel sequential measurement were apparent at times; this would be easily overcome in a three-channel concurrent system. Calibration would gain from a pure $\mathrm{HONO}$ source; currently the $\mathrm{pHONO}$ calibration requires an independent, direct $\mathrm{NO}_{2}$ measurement and $\mathrm{NO}_{y}$ measurement.

\section{Data availability}

We thank the NASA Jet Propulsion Laboratory (Burkholder et al., 2015) for providing comprehensive absorption crosssection data for atmospheric compounds, which can be found at http://jpldataeval.jpl.nasa.gov.

\section{The Supplement related to this article is available online at doi:10.5194/amt-9-2483-2016-supplement.}

Acknowledgements. The authors would like to express their gratitude to Marty Buhr of Air Quality Design Inc. for their support, and Lisa Whalley of Leeds for spectral radiometer/calibration equipment. Iustinian Bejan, formerly of Leeds, receives thanks for his invaluable guidance in HONO quantification within HIRAC. The financial support of the Engineering and Physical Sciences Research Council (ESPRC) for the studentship of Charlotte Brumby and the financial support of NCAS, the National Centre 
for Atmospheric Science, and of NERC, the Natural Environmental Research Council for supporting the studentship of Chris Reed, are gratefully acknowledged.

Edited by: R. Cohen

\section{References}

Acker, K., Möller, D., Auel, R., Wieprecht, W., and Kalaß, D.: Concentrations of nitrous acid, nitric acid, nitrite and nitrate in the gas and aerosol phase at a site in the emission zone during ESCOMPTE 2001 experiment, Atmos. Res., 74, 507-524, doi:10.1016/j.atmosres.2004.04.009, 2005.

Acker, K., Febo, A., Trick, S., Perrino, C., Bruno, P., Wiesen, P., Möller, Wieprecht, W., Auel, R., Giusto, M., Geyer, A., Platt, U., and Allegrini, I.: Nitrous acid in the urban area of Rome, Atmos. Environ., 40, 3123-3133, doi:10.1016/j.atmosenv.2006.01.028, 2006.

Atkinson, R., Baulch, D. L., Cox, R. A., Crowley, J. N., Hampson, R. F., Hynes, R. G., Jenkin, M. E., Rossi, M. J., and Troe, J.: Evaluated kinetic and photochemical data for atmospheric chemistry: Volume $\mathrm{I}-$ gas phase reactions of $\mathrm{O}_{x}, \mathrm{HO}_{x}, \mathrm{NO}_{x}$ and $\mathrm{SO}_{x}$ species, Atmos. Chem. Phys., 4, 1461-1738, doi:10.5194/acp-41461-2004, 2004.

Barney, W. S., Wingen, L. M., Lakin, M. J., Brauers, T., Stutz, J., and Finlayson-Pitts, B. J.: Infrared absorption cross-section measurements for nitrous acid (HONO) at room temperature, J. Phys. Chem. A, 104, 1692-1699, doi:10.1021/jp9930503, 2000.

Beine, H. J., Amoroso, A., Dominé, F., King, M. D., Nardino, M., Ianniello, A., and France, J. L.: Surprisingly small HONO emissions from snow surfaces at Browning Pass, Antarctica, Atmos. Chem. Phys., 6, 2569-2580, doi:10.5194/acp-6-2569-2006, 2006.

Beine, H., Colussi, A. J., Amoroso, A., Esposito, G., Montagnoli, M., and Hoffmann, M. R.: HONO emissions from snow surfaces, Environ. Res. Lett., 3, 045005, doi:10.1088/17489326/3/4/045005, 2008.

Boggs, P. T., Byrd, R. H., and Schnabel, R. B.: A Stable and Efficient Algorithm for Nonlinear Orthogonal Distance Regression, SIAM J. Sci. Stat. Comput., 8, 1052-1078, doi:10.1137/0908085, 1987.

Bröske, R., Kleffmann, J., and Wiesen, P.: Heterogeneous conversion of $\mathrm{NO}_{2}$ on secondary organic aerosol surfaces: A possible source of nitrous acid (HONO) in the atmosphere?, Atmos. Chem. Phys., 3, 469-474, doi:10.5194/acp-3-469-2003, 2003.

Buhr, M.: Measurement of $\mathrm{NO}_{2}$ in ambient air using a solid-state photolytic converter, in Symposium on Air Quality Measurement Methods and Technology 2004, 20-22 April 2004, 165171, Cary, NC, USA, 2004.

Buhr, M.: Solid-State Light Source Photolytic Nitrogen Dioxide Converter, US 7238328 B2, United States, USTPO, available at: https://www.google.co.uk/patents/US7238328 (last access: 26 March 2016), 3 July 2007.

Burkholder, J. B., Sander, S. P., Abbatt, J., Barker, J. R., Huie, R. E., Kolb, C. E., Kurylo, M. J., Orkin, V. L., Wilmouth, D. M., and Wine, P. H.: Chemical Kinetics and Photochemical Data for Use in Atmospheric Studies, Evaluation No. 18, JPL Publication
15-10, Jet Propulsion Laboratory, Pasadena, USA, available at: http://jpldataeval.jpl.nasa.gov (last access: 28 April 2016), 2015.

Carroll, R. J. and Ruppert, D.: The Use and Misuse of Orthogonal Regression in Linear Errors-in-Variables Models, Am. Stat., 50, 1-6, doi:10.1080/00031305.1996.10473533, 1996.

Clemitshaw, K. C.: A Review of Instrumentation and Measurement Techniques for Ground-Based and Airborne Field Studies of Gas-Phase Tropospheric Chemistry, Crit. Rev. Environ. Sci. Technol., 34, 1-108, doi:10.1080/10643380490265117, 2004.

Cleveland, W. S.: Robust Locally Weighted Regression and Smoothing Scatterplots, J. Am. Stat. Assoc., 74, 829-836, doi:10.2307/2286407, 1979.

Del Negro, L. A., Fahey, D. W., Gao, R. S., Donnelly, S. G., Keim, E. R., Neuman, J. A., Cohen, R. C., Perkins, K. K., Koch, L. C., Salawitch, R. J., Lloyd, S. A., Proffitt, M. H., Margitan, J. J., Stimpfle, R. M., Bonne, G. P., Voss, P. B., Wennberg, P. O., McElroy, C. T., Swartz, W. H., Kusterer, T. L., Anderson, D. E., Lait, L. R., and Bui, T. P.: Comparison of modeled and observed values of $\mathrm{NO}_{2}$ and $\mathrm{JNO}_{2}$ during the Photochemistry of Ozone Loss in the Arctic Region in Summer (POLARIS) mission, J. Geophys. Res. Atmos., 104, 26687-26703, doi:10.1029/1999JD900246, 1999.

Drummond, J. W., Volz, A., and Ehhalt, D. H.: An optimized chemiluminescence detector for tropospheric NO measurements, J. Atmos. Chem., 2, 287-306, doi:10.1007/BF00051078, 1985.

Elshorbany, Y. F., Kurtenbach, R., Wiesen, P., Lissi, E., Rubio, M., Villena, G., Gramsch, E., Rickard, A. R., Pilling, M. J., and Kleffmann, J.: Oxidation capacity of the city air of Santiago, Chile, Atmos. Chem. Phys., 9, 2257-2273, doi:10.5194/acp-92257-2009, 2009.

Febo, A., Perrino, C., and Cortiello, M.: A denuder technique for the measurement of nitrous acid in urban atmospheres, Atmos. Environ. Part A. Gen. Top., 27, 1721-1728, doi:10.1016/09601686(93)90235-Q, 1993.

Febo, A., Perrino, C., Gherardi, M., and Sparapani, R.: Evaluation of a High-Purity and High-Stability Continuous Generation System for Nitrous Acid, Environ. Sci., 29, 2390-2395, doi:10.1021/es00009a035, 1995.

Febo, A., Perrino, C., and Allegrini, I.: Measurement of Nitrous Acid in Milan, Italy, By Doas and Diffusion Denuders, Atmos. Environ., 30, 3599-3609, doi:10.1016/1352-2310(96)00069-6, 1996.

Fehsenfeld, F. C., Dickerson, R. R., Hobler, G., Luke, W. T., Nunnermacker, L. J., Roberts, J. M., Curran, C. M., Eubank, C. S., Fahey, D. W., Mindplay, P. C., and Pickering, K. E.: A Ground-Based Intercomparison of $\mathrm{NO}, \mathrm{NO}_{x}$, and $\mathrm{NO}_{y}$ Measurement Techniques, J. Geophys. Res., 92, 710-722, doi:10.1029/JD092iD12p14710, 1987.

Finlayson-Pitts, B. J., Wingen, L. M., Sumner, A. L., Syomin, D., and Ramazan, K. A.: The heterogeneous hydrolysis of NO2 in laboratory systems and in outdoor and indoor atmospheres: An integrated mechanism, Phys. Chem. Chem. Phys., 5, 223-242, doi:10.1039/B208564J, 2003.

Gao, R. S., Keim, E. R., Woodbridge, E. L., Ciciora, S. J., Proffitt, M. H., Thompson, T. L., Mclaughlin, R. J., and Fahey, D. W.: New photolysis system for $\mathrm{NO}_{2}$ measurements in the lower stratosphere, J. Geophys. Res., 99, 673-681, doi:10.1029/94JD01521, 1994. 
Gligorovski, S.: Nitrous acid (HONO): An emerging indoor pollutant, J. Photochem. Photobiol. A Chem., 314, 1-5, doi:10.1016/j.jphotochem.2015.06.008, 2016.

Glowacki, D. R., Goddard, A., Hemavibool, K., Malkin, T. L., Commane, R., Anderson, F., Bloss, W. J., Heard, D. E., Ingham, T., Pilling, M. J., and Seakins, P. W.: Design of and initial results from a Highly Instrumented Reactor for Atmospheric Chemistry (HIRAC), Atmos. Chem. Phys., 7, 5371-5390, doi:10.5194/acp7-5371-2007, 2007a.

Glowacki, D. R., Goddard, A., and Seakins, P. W.: Design and performance of a throughput-matched, zero-geometric-loss, modified three objective multipass matrix system for FTIR spectrometry, Appl. Opt., 46, 7872-7883, doi:10.1364/AO.46.007872, 2007b.

Gutzwiller, L., Arens, F., Baltensperger, U., Gäggeler, H. W., and Ammann, M.: Significance of semivolatile diesel exhaust organics for secondary HONO formation, Environ. Sci. Technol., 36, 677-682, doi:10.1021/es015673b, 2002.

Heland, J., Kleffmann, J., Kurtenbach, R., and Wiesen, P.: A new instrument to measure gaseous nitrous acid (HONO) in the atmosphere, Environ. Sci. Technol., 35, 3207-3212, doi:10.1021/es000303t, 2001.

Hendrick, F., Müller, J.-F., Clémer, K., Wang, P., De Mazière, M., Fayt, C., Gielen, C., Hermans, C., Ma, J. Z., Pinardi, G., Stavrakou, T., Vlemmix, T., and Van Roozendael, M.: Four years of ground-based MAX-DOAS observations of HONO and NO2 in the Beijing area, Atmos. Chem. Phys., 14, 765-781, doi:10.5194/acp-14-765-2014, 2014.

Ianniello, A., Beine, H. J., Landis, M. S., Stevens, R. K., Esposito, G., Amoroso, A., and Allegrini, I.: Comparing field performances of denuder techniques in the high Arctic, Atmos. Environ., 41, 1604-1615, doi:10.1016/j.atmosenv.2006.10.040, 2007.

Kanaya, Y., Cao, R., Akimoto, H., Fukuda, M., Komazaki, Y., Yokouchi, Y., Koike, M., Tanimoto, H., Takegawa, N., and Kondo, Y.: Urban photochemistry in central Tokyo: 1. Observed and modeled $\mathrm{OH}$ and $\mathrm{HO}_{2}$ radical concentrations during the winter and summer of 2004, J. Geophys. Res., 112, D21312, doi:10.1029/2007JD008670, 2007.

Kebabian, P. L. and Freedman, A.: System and method for trace species detection using cavity attenuated phase shift spectroscopy with an incoherent light source, US7301639 B1, United States, USTPO, available at: http://www.google.co.uk/patents/ US7301639 (last access: 26 March 2016), 27 November 2007.

Kebabian, P. L., Herndon, S. C., and Freedman, A.: Detection of nitrogen dioxide by cavity attenuated phase shift spectroscopy, Anal. Chem., 77, 724-728, doi:10.1021/ac048715y, 2005.

Kebabian, P. L., Wood, E. C., Herndon, S. C., and Freedman, A.: A practical alternative to chemiluminescence-based detection of nitrogen dioxide: Cavity attenuated phase shift spectroscopy, Environ. Sci. Technol., 42, 6040-6045, doi:10.1021/es703204j, 2008.

Kim, S., VandenBoer, T. C., Young, C. J., Riedel, T. P., Thornton, J. A., Swarthout, B., Sive, B., Lerner, B. M., Gilman, J. B., Warneke, C., Roberts, J. M., Guenther, A., Wagner, N. L., Dubé, W. P., Williams, E. J., and Brown, S. S.: The primary and recyling sources of $\mathrm{OH}$ during the NACHTT2011 campaign: $\mathrm{HONO}$ as an important $\mathrm{OH}$ primary source in the wintertime, J. Geophys. Res. Atmos., 119, 6886-6896, doi:10.1002/2013JD021272, 2014.
Kleffmann, J.: Daytime sources of nitrous acid (HONO) in the atmospheric boundary layer, Chem. Phys. Chem., 8, 1137-1144, doi:10.1002/cphc.200700016, 2007.

Kleffmann, J. and Wiesen, P.: Technical Note: Quantification of interferences of wet chemical HONO LOPAP measurements under simulated polar conditions, Atmos. Chem. Phys., 8, 6813-6822, doi:10.5194/acp-8-6813-2008, 2008.

Kleffmann, J., Lörzer, J. C., Wiesen, P., Kern, C., Trick, S., Volkamer, R., Rodenas, M., and Wirtz, K.: Intercomparison of the DOAS and LOPAP techniques for the detection of nitrous acid (HONO), Atmos. Environ., 40, 3640-3652, doi:10.1016/j.atmosenv.2006.03.027, 2006.

Kleffmann, J., Villena Tapia, G., Bejan, I., Kurtenbach, R., and Wiesen, P.: $\mathrm{NO}_{2}$ Measurement Techniques: Pitfalls and New Developments, edited by I. Barnes and K. J. Rudziński, NATO Sci. Peace Secur. Ser. C Environ. Secur., 120, 15-28, doi:10.1007/978-94-007-5034-0, 2013.

Lammel, G. and Cape, J. N.: Nitrous acid and nitrite in the atmosphere, Chem. Soc. Rev., 25, 361, doi:10.1039/cs9962500361, 1996.

Lee, B. H., Santoni, G. W., Wood, E. C., Herndon, S. C., MiakeLye, R. C., Zahniser, M. S., Wofsy, S. C., and Munger, J. W.: Measurements of nitrous acid in commercial aircraft exhaust at the alternative aviation fuel experiment, Environ. Sci. Technol., 45, 7648-7654, doi:10.1021/es200921t, 2011a.

Lee, B. H., Wood, E. C., Zahniser, M. S., McManus, J. B., Nelson, D. D., Herndon, S. C., Santoni, G. W., Wofsy, S. C., and Munger, J. W.: Simultaneous measurements of atmospheric HONO and $\mathrm{NO}_{2}$ via absorption spectroscopy using tunable mid-infrared continuous-wave quantum cascade lasers, Appl. Phys. B Lasers Opt., 102, 417-423, doi:10.1007/s00340-010-4266-5, $2011 \mathrm{~b}$.

Lee, B. H., Wood, E. C., Wormhoudt, J., Shorter, J. H., Herndon, S. C., Zahniser, M. S., and Munger, J. W.: Effective line strengths of trans-nitrous acid near $1275 \mathrm{~cm}^{-1}$ and cis-nitrous acid at $1660 \mathrm{~cm}^{-1}$, J. Quant. Spectrosc. Radiat. Transf., 113, 1905-1912, doi:10.1016/j.jqsrt.2012.06.004, 2012.

Lee, J. D., Moller, S. J., Read, K. A., Lewis, A. C., Mendes, L., and Carpenter, L. J.: Year-round measurements of nitrogen oxides and ozone in the tropical North Atlantic marine boundary layer, J. Geophys. Res., 114, D21302, doi:10.1029/2009JD011878, 2009.

Lee, J. D., Whalley, L. K., Heard, D. E., Stone, D., Dunmore, R. E., Hamilton, J. F., Young, D. E., Allan, J. D., Laufs, S., and K1effmann, J.: Detailed budget analysis of HONO in central London reveals a missing daytime source, Atmos. Chem. Phys., 16, 2747-2764, doi:10.5194/acp-16-2747-2016, 2016.

Levy II, H.: Photochemistry of minor constituents in the troposphere, Planet. Space Sci., 21, 575-591, doi:10.1016/00320633(73)90071-8, 1973.

Levy, M., Zhang, R., Zheng, J., Zhang, A. L., Xu, W., GomezHernandez, M., Wang, Y., and Olaguer, E.: Measurements of nitrous acid (HONO) using ion drift-chemical ionization mass spectrometry during the 2009 SHARP field campaign, Atmos. Environ., 94, 231-240, doi:10.1016/j.atmosenv.2014.05.024, 2014.

Markovic, M. Z., VandenBoer, T. C., and Murphy, J. G.: Characterization and optimization of an online system for the simultaneous measurement of atmospheric water-soluble constituents in the gas and particle phases, J. Environ. Monit., 14, 1872, doi:10.1039/c2em00004k, 2012. 
Oswald, R., Behrendt, T., Ermel, M., Wu, D., Su, H., Cheng, Y., Breuninger, C., Moravek, A., Mougin, E., Delon, C., Loubet, B., Pommerening-Röser, A., Sörgel, M., Pöschl, U., Hoffmann, T., Andreae, M. O., Meixner, F. X., and Trebs, I.: HONO emissions from soil bacteria as a major source of atmospheric reactive nitrogen, Science, 341, 1233-1235, doi:10.1126/science.1242266, 2013.

Penkett, S. A., Plane, J. M. C., Comes, F. J., Clemitshaw, K. C., and Coe, H.: The Weybourne Atmospheric Observatory, J. Atmos. Chem., 33, 107-110, doi:10.1023/A:1026428102821, 1999.

Pollack, I. B., Lerner, B. M., and Ryerson, T. B.: Evaluation of ultraviolet light-emitting diodes for detection of atmospheric $\mathrm{NO}_{2}$ by photolysis - chemiluminescence, J. Atmos. Chem., 65, 111-125, doi:10.1007/s10874-011-9184-3, 2011.

Pusede, S. E., Gentner, D. R., Wooldridge, P. J., Browne, E. C., Rollins, A. W., Min, K.-E., Russell, A. R., Thomas, J., Zhang, L., Brune, W. H., Henry, S. B., DiGangi, J. P., Keutsch, F. N., Harrold, S. A., Thornton, J. A., Beaver, M. R., St. Clair, J. M., Wennberg, P. O., Sanders, J., Ren, X., VandenBoer, T. C., Markovic, M. Z., Guha, A., Weber, R., Goldstein, A. H., and Cohen, R. C.: On the temperature dependence of organic reactivity, nitrogen oxides, ozone production, and the impact of emission controls in San Joaquin Valley, California, Atmos. Chem. Phys., 14, 3373-3395, doi:10.5194/acp-14-3373-2014, 2014.

Rappengluck, B., Lubertino, G., Alvarez, S., Golovko, J., Czader, B., and Ackermann, L.: Radical precursors and related species from traffic as observed and modeled at an urban highway junction, J. Air Waste Manag. Assoc., 63, 1270-1286, doi:10.1080/10962247.2013.822438, 2013.

Rattigan, O., Lutman, E., Jones, R. L., Cox, R. A., Clemitshaw, K., and Williams, J.: Temperature-dependent absorption crosssections of gaseous nitric acid and methyl nitrate, J. Photochem. Photobiol. A Chem., 66, 313-326, doi:10.1016/10106030(92)80003-E, 1992.

Reed, C., Evans, M. J., Di Carlo, P., Lee, J. D., and Carpenter, L. J.: Interferences in photolytic NO2 measurements: explanation for an apparent missing oxidant?, Atmos. Chem. Phys., 16, 47074724, doi:10.5194/acp-16-4707-2016, 2016.

Ren, X., Gao, H., Zhou, X., Crounse, J. D., Wennberg, P. O., Browne, E. C., LaFranchi, B. W., Cohen, R. C., McKay, M., Goldstein, A. H., and Mao, J.: Measurement of atmospheric nitrous acid at Bodgett Forest during BEARPEX2007, Atmos. Chem. Phys., 10, 6283-6294, doi:10.5194/acp-10-6283-2010, 2010.

Ren, X., Sanders, J. E., Rajendran, A., Weber, R. J., Goldstein, A. H., Pusede, S. E., Browne, E. C., Min, K.-E., and Cohen, R. C.: A relaxed eddy accumulation system for measuring vertical fluxes of nitrous acid, Atmos. Meas. Tech., 4, 2093-2103, doi:10.5194/amt-4-2093-2011, 2011.

Ridley, B. A., Carroll, M. A., Torres, A. L., Condon, E. P., Sachse, G. W., Hill, G. F., and Gregory, G. L.: An intercomparison of results from ferrous sulphate and photolytic converter techniques for measurements of $\mathrm{NO}_{x}$ made during the NASA GTE/CITE 1 aircraft program, J. Geophys. Res., 93, 1580315811, doi:10.1029/JD093iD12p15803, 1988.

Roberts, J. M., Veres, P., Warneke, C., Neuman, J. A., Washenfelder, R. A., Brown, S. S., Baasandorj, M., Burkholder, J. B., Burling, I. R., Johnson, T. J., Yokelson, R. J., and de Gouw, J.: Measurement of HONO, HNCO, and other inorganic acids by negative-ion proton-transfer chemical-ionization mass spectrometry (NI-PT-CIMS): application to biomass burning emissions, Atmos. Meas. Tech., 3, 981-990, doi:10.5194/amt-3-981-2010, 2010.

Ródenas, M., Muñoz, A., Alacreu, F., Brauers, T., Dorn, H.-P., Kleffmann, J., and Bloss, W.: Assessment of HONO Measurements: The FIONA Campaign at EUPHORE, in Disposal of Dangerous Chemicals in Urban Areas and Megacities, NATO Science for Peace \& Security Series C: Environmental Security, . 45-58., 2013.

Ryerson, T. B., Williams, E. J., and Fehsenfeld, F. C.: An efficient photolysis system for fast-response NO2 measurements, J. Geophys. Res., 105, 26447-26461, doi:10.1029/2000JD900389, 2000.

Sadanaga, Y., Fukumori, Y., Kobashi, T., Nagata, M., Takenaka, N., and Bandow, H.: Development of a selective lightemitting diode photolytic $\mathrm{NO}_{2}$ converter for continuously measuring $\mathrm{NO}_{2}$ in the atmosphere, Anal. Chem., 82, 9234-9239, doi:10.1021/ac101703z, 2010.

Sadanaga, Y., Suzuki, K., Yoshimoto, T., and Bandow, H.: Direct measurement system of nitrogen dioxide in the atmosphere using a blue light-emitting diode induced fluorescence technique., Rev. Sci. Instrum., 85, 064101, doi:10.1063/1.4879821, 2014.

Sörgel, M., Regelin, E., Bozem, H., Diesch, J.-M., Drewnick, F., Fischer, H., Harder, H., Held, A., Hosaynali-Beygi, Z., Martinez, M., and Zetzsch, C.: Quantification of the unknown HONO daytime source and its relation to $\mathrm{NO}_{2}$, Atmos. Chem. Phys., 11, 10433-10447, doi:10.5194/acp-11-10433-2011, 2011.

Spataro, F. and Ianniello, A.: Sources of atmospheric nitrous acid: State of the science, current research needs, and future prospects, J. Air Waste Manage. Assoc., 64, 1232-1250, doi:10.1080/10962247.2014.952846, 2014.

Stark, H., Lerner, B. M., Schmitt, R., Jakoubek, R., Williams, E. J., Ryerson, T. B., Sueper, D. T., Parrish, D. D., and Fehsenfeld, F. C.: Atmospheric in situ measurement of nitrate radical $\left(\mathrm{NO}_{3}\right)$ and other photolysis rates using spectroradiometry and filter radiometry, J. Geophys. Res., 112, 1-11, doi:10.1029/2006jd007578, 2007.

Stutz, J.: Relative humidity dependence of HONO chemistry in urban areas, J. Geophys. Res., 109, D03307, doi:10.1029/2003JD004135, 2004.

Stutz, J., Oh, H. J., Whitlow, S. I., Anderson, C., Dibb, J. E., Flynn, J. H., Rappenglück, B., and Lefer, B.: Simultaneous DOAS and mist-chamber IC measurements of HONO in Houston, TX, Atmos. Environ., 44, 4090-4098, doi:10.1016/j.atmosenv.2009.02.003, 2010.

Su, H., Cheng, Y., Oswald, R., Behrendt, T., Trebs, I., Meixner, F. X., Andreae, M. O., Cheng, P., Zhang, Y., and Pöschl, U.: Soil nitrite as a source of atmospheric $\mathrm{HONO}$ and $\mathrm{OH}$ radicals., Science, 333, 1616-1618, doi:10.1126/science.1207687, 2011.

Taira, M. and Kanda, Y.: Continuous generation system for lowconcentration gaseous nitrous acid, Anal. Chem., 633, 630-633, doi:10.1021/ac00205a018, 1990.

Vandenboer, T. C., Markovic, M. Z., Sanders, J. E., Ren, X., Pusede, S. E., Browne, E. C., Cohen, R. C., Zhang, L., Thomas, J., Brune, W. H., and Murphy, J. G.: Evidence for a nitrous acid (HONO) reservoir at the ground surface in Bakersfield, CA, during CalNex 2010, J. Geophys. Res. Atmos., 119, 9093-9106, doi:10.1002/2013JD020971, 2014. 
Villena, G., Bejan, I., Kurtenbach, R., Wiesen, P., and Kleffmann, J.: Interferences of commercial $\mathrm{NO}_{2}$ instruments in the urban atmosphere and in a smog chamber, Atmos. Meas. Tech., 5, 149-159, doi:10.5194/amt-5-149-2012, 2012.

Villena, G., Bejan, I., Kurtenbach, R., Wiesen, P., and Kleffmann, J.: Development of a new Long Path Absorption Photometer (LOPAP) instrument for the sensitive detection of $\mathrm{NO}_{2}$ in the atmosphere, Atmos. Meas. Tech., 4, 1663-1676, doi:10.5194/amt4-1663-2011, 2011a.

Villena, G., Kleffmann, J., Kurtenbach, R., Wiesen, P., Lissi, E., Rubio, M. A., Croxatto, G., and Rappenglück, B.: Vertical gradients of $\mathrm{HONO}, \mathrm{NO}_{x}$ and $\mathrm{O}_{3}$ in Santiago de Chile, Atmos. Environ., 45, 3867-3873, doi:10.1016/j.atmosenv.2011.01.073, $2011 \mathrm{~b}$.

Volkamer, R., Spietz, P., Burrows, J., and Platt, U.: High-resolution absorption cross-section of glyoxal in the UV-vis and IR spectral ranges, J. Photochem. Photobiol. A Chem., 172, 35-46, doi:10.1016/j.jphotochem.2004.11.011, 2005.

Weber, B., Wu, D., Tamm, A., Ruckteschler, N., RodríguezCaballero, E., Steinkamp, J., Meusel, H., Elbert, W., Behrendt, T., Sörgel, M., Cheng, Y., Crutzen, P. J., Su, H., and Pöschl, U.: Biological soil crusts accelerate the nitrogen cycle through large $\mathrm{NO}$ and HONO emissions in drylands, Proc. Natl. Acad. Sci., 112, 201515818, doi:10.1073/pnas.1515818112, 2015.

Whalley, L. K., Blitz, M. A., Desservettaz, M., Seakins, P. W., and Heard, D. E.: Reporting the sensitivity of laser-induced fluorescence instruments used for $\mathrm{HO}_{2}$ detection to an interference from $\mathrm{RO}_{2}$ radicals and introducing a novel approach that enables $\mathrm{HO}_{2}$ and certain $\mathrm{RO}_{2}$ types to be selectively measured, Atmos. Meas. Tech., 6, 3425-3440, doi:10.5194/amt-6-3425-2013, 2013.
Williams, E. J., Baumann, K., Roberts, J. M., Bertman, S. B., Norton, R. B., Fehsenfeld, F. C., Sprinston, S. R., Nunnermacker, L. J., Newman, L., Olszyna, K., Meagher, J. F., Hartsell, B., Edgerton, E. S., Pearson, J. R., and Rodgers, M. O.: Intercomparison of ground-based NOy measurement techniques, J. Geophys. Res., 103, 22261-22280, doi:10.1029/98JD00074, 1998.

Yang, X., Cox, R. A., Warwick, N. J., Pyle, J. A., Carver, G. D., O'Connor, F. M., and Savage, N. H.: Tropospheric bromine chemistry and its impacts on ozone: A model study, J. Geophys. Res., 110, D23311, doi:10.1029/2005JD006244, 2005.

Zhang, N., Zhou, X., Shepson, P. B., Gao, H., Alaghmand, M., and Stirm, B.: Aircraft measurement of HONO vertical profiles over a forested region, Geophys. Res. Lett., 36, 1-5, doi:10.1029/2009GL038999, 2009.

Zhang, N., Zhou, X., Bertman, S., Tang, D., Alaghmand, M., Shepson, P. B., and Carroll, M. A.: Measurements of ambient HONO concentrations and vertical HONO flux above a northern Michigan forest canopy, Atmos. Chem. Phys., 12, 8285-8296, doi:10.5194/acp-12-8285-2012, 2012.

Zhou, X., Beine, H. J., Honrath, R. E., Fuentes, J. D., Simpson, W., Shepson, P. B., and Bottenheim, J. W.: Snowpack Photochemical Production of HONO: a Major Source of $\mathrm{OH}$ in the Arctic Boundary Layer, Geophys. Res. Lett., 28, 4087-4090, doi:10.1029/2001GL013531, 2001. 